\title{
Investor attention and stock returns -An empirical study based on WeChat index
}

\author{
Liu Jiajian, He Qirong, Yang Zongru \\ School of economics and management, Beijing Jiaotong University, Beijing \\ School of mathematics, Beijing Jiaotong University, Beijing \\ School of economics and management, Beijing Jiaotong University, Beijing
}

Keywords: WeChat index, investor attention, stock returns

\begin{abstract}
This paper is based on WeChat index, at first, 5 industries which are closely related to the daily life of Wechat users in stock markets are selected randomly, they are retail, securities, media, clothing, home textiles, food processing and manufacturing. After that, we select 30 stocks from 5 different industries as the research object, take the data provided by WeChat index as a measure of investor attention, build panel data model to research on the relationship between investor attention and stock returns. Finally, according to the research results: Investors' attention is proportional to stock returns in the same period; reversal after positive impact.
\end{abstract}

\section{Introduction}

China's stock market is dominated by individual investors. In today's information explosion, the problem faced by individual investors is how to effectively and quickly find information that helps investment decisions in the vast amounts of information. However, individual attention is a scarce resource, there is an obvious contradiction between the huge amount of information and the ability of individual to obtain consumption information. Under such circumstances, the study of investor attention becomes more and more important.

At present, one of the difficulties in this field is the quantification of investors' attention. At present, there is no clear unified standard in the academic circle. With the development of the Internet, more and more people search for information through search engines, based on the data provided by the search engine (Baidu index, Google trend, WeChat index, etc.) can more objectively reflect the degree of investor attention. Based on this, this paper uses WeChat index as investor attention index to study the relationship between investor attention and stock returns.

\section{Literature review}

\subsection{Investor attention metrics}

The measurement of investors' attention is still one of the difficult problems in academic research. Scholars at home and abroad have conducted in-depth research, but there is still no objective standard to measure investor attention. Some foreign scholars use indirect indicators to build investor attention. Such as Gervais, Kaniel and Mingelgrin (2001) used to measure the stock trading volume; Seasholes and $\mathrm{Wu}$ (2008) choose extreme deals to measure, they believe stock market report will affect investors' attention; Fang and Press (2009) choose media coverage (the number of authoritative newspaper) to measure;

On the other hand, the domestic scholars also use some proxy variables to measure the degree of attention from investors, such as Jia Chunxin, etc. With the development of internet technology, more and more scholars take the Internet data as a metric., such as Ying Qianqwei, Luo Danglun(2014) use the Baidu index to construct investors' attention weekly index; Zhu Nanli, Zouping, Zhang Yongping, etc, construct investor attention index based on blog / micro-blog information; Yu Qingjin, Zhang Bing also use Baidu index as a measure of investor attention; Similarly, other scholars take the objective data provided by the Internet search engine as the proxy variable. Therefore, this paper constructs the investor attention index from the angle of WeChat 
index which is relatively objective.

\subsection{The relationship between stock returns and investor attention (Internet based)}

With the development of behavioral finance, more researchers have put investor psychological factors into the study, and many studies have shown that investor concern has a close relationship with the change of stock price. At present, some scholars in China have paid much attention to the investors' attention based on the objective Internet data of Baidu index. Wang Zhen and Hao Gang (2013) found that investors' attention had a positive impact on stock returns, and the earlier concerns had negative effects by setting up panel data model; Ying Qianqwei, Luo Danglun, Kong Dongming's (2014) regression analysis shows that investor attention has a significant impact on the next week's earnings, and that the effect is reversed after a week, and that the impact will not be offset within a year; Liu Feng, Ye Qiang, Li Yijun (2014) found that the influence of media attention on stock returns was significantly weaker than the influence of investor attention on stock returns. Moreover, it is the investors' attention and investment behavior caused by media information transmission that lead to changes in stock returns; On the whole, the qualitative research of investor attention based on objective Internet data shows that stock change is closely related to investor attention.

The foreign scholars in this study use the agency variables in the objectivity of the shortcomings, while the domestic researchers use the Baidu index, which is now not consistent with the times.

(With the rapid development of WeChat, its data become more and more representative.) Therefore, the WeChat index is more objective and representative, more close to the actual market situation, so the research is more convincing.

\section{Research design}

\subsection{Sample selection}

At present, as a new Internet Ecosystem, WeChat itself has become a way of life. So WeChat index is more related with the real economy. Based on this situation, in order to make the correlation between sample data and investor attention stronger, we selected samples from retail, securities, media, clothing, home textiles, food processing and manufacturing industries as sample data. In order to ensure the accuracy of the empirical results, we use the random selection method to select 5 companies from six industries, the sample data are as follows:

Table 1 sample data

\begin{tabular}{ccc}
\hline Industry & Stock name & Stock code \\
\hline Retail & Yonghui Superstores Co., Ltd. & 601933 \\
\hline Retail & Chang Chun Eurasia Group Co., & 600697 \\
Ltd. & $\begin{array}{c}\text { Lepartment Store Co., } \\
\text { Ltd. }\end{array}$ & 600712 \\
\hline Retail & $\begin{array}{c}\text { Chongqing Department Store } \\
\text { Co., Ltd. }\end{array}$ & 600729 \\
\hline Retail & Co., Ltd. & 600361 \\
\hline Retail & $\begin{array}{c}\text { Beijing Hualian Hypermarket } \\
\text { Media }\end{array}$ & 600977 \\
\hline Media & $\begin{array}{c}\text { Chinese Universe Publishing } \\
\text { and Media Co., Ltd. }\end{array}$ & 600373 \\
\hline Media & Beijing Bashi Media Co., Ltd. & 600386 \\
\hline Media & $\begin{array}{c}\text { Jiangsu Phoenix Publishing and } \\
\text { Media Corporation Limited }\end{array}$ & 601928 \\
\hline Media & $\begin{array}{c}\text { Shanghai Film Co., Ltd. } \\
\text { CITIC Securities Company } \\
\text { Lecurities }\end{array}$ & 601595 \\
\hline
\end{tabular}




\begin{tabular}{|c|c|c|}
\hline Securities & Southwest Securities Co., Ltd. & 600369 \\
\hline Securities & $\begin{array}{c}\text { Central China Securities Co., } \\
\text { Ltd. }\end{array}$ & 601375 \\
\hline Securities & $\begin{array}{c}\text { Guotai Junan Securities Co., } \\
\text { Ltd. }\end{array}$ & 601211 \\
\hline Securities & Huatai Securities Co., Ltd. & 601688 \\
\hline Clothing and home textile & $\begin{array}{l}\text { Zhejiang Red Dragonfly } \\
\text { Footware Co., Ltd. }\end{array}$ & 603116 \\
\hline Clothing and home textile & $\begin{array}{l}\text { Ningbo Peacebird Fashion Co., } \\
\text { Ltd. }\end{array}$ & 603877 \\
\hline Clothing and home textile & Heilan Home Co., Ltd. & 600398 \\
\hline Clothing and home textile & $\begin{array}{l}\text { Jiangsu Hongdou Industry Co., } \\
\text { Ltd. }\end{array}$ & 600400 \\
\hline Clothing and home textile & Sichuan Langsha Holding Ltd. & 600137 \\
\hline $\begin{array}{l}\text { Food processing and } \\
\text { manufacturing }\end{array}$ & $\begin{array}{l}\text { Inner Mongolia Yili Industrial } \\
\text { Group Co., Ltd. }\end{array}$ & 600887 \\
\hline $\begin{array}{l}\text { Food processing and } \\
\text { manufacturing }\end{array}$ & Beijing Sanyuan Foods Co., Ltd. & 600429 \\
\hline $\begin{array}{l}\text { Food processing and } \\
\text { manufacturing }\end{array}$ & $\begin{array}{l}\text { Meihua Holdings Group Co., } \\
\text { Ltd. }\end{array}$ & 600873 \\
\hline $\begin{array}{l}\text { Food processing and } \\
\text { manufacturing }\end{array}$ & Juewei Food Co., Ltd. & 603517 \\
\hline $\begin{array}{l}\text { Food processing and } \\
\text { manufacturing }\end{array}$ & $\begin{array}{l}\text { Xinjiang Tianrun Dairy Co., } \\
\text { Ltd. }\end{array}$ & 600419 \\
\hline The home appliance & Qingdao Haier Co., Ltd. & 600690 \\
\hline The home appliance & $\begin{array}{l}\text { Shanghai Flyco Electrical } \\
\text { Appliance Co., Ltd. }\end{array}$ & 603868 \\
\hline The home appliance & $\begin{array}{l}\text { Jiangsu Sunrain Solar Energy } \\
\text { Co., Ltd. }\end{array}$ & 603366 \\
\hline The home appliance & $\begin{array}{l}\text { Jiangsu Chunlan Refrigerating } \\
\text { Equipment Stock Co., Ltd. }\end{array}$ & 600854 \\
\hline The home appliance & $\begin{array}{c}\text { Zhejiang Langdi Group Co., } \\
\text { Ltd. }\end{array}$ & 603726 \\
\hline
\end{tabular}

\subsection{Variable definition}

RET (I stock T return) - dependent variable, the stock return is a weekly stock return, the time span is one month;

AT (investor attention index), the independent variable, the median of investor attention and the logarithm are selected;

PB (the I stock T futures net rate) - controlled variable Turnover (I phase T stock turnover rate)

\subsection{Data collection}

The stock returns from investor attention are derived from the resset database. The research time is from May 8th to June 8th. The effect of investor attention on the next week is studied by week. The time span is one month. The collection of investor attention data comes from manually collecting WeChat index.

\subsection{Model establishment}

To construct the monthly rate of return as explanatory variables, to ordinary investors, the company scale, city net rate of explanatory variables in the panel regression model, the model is as follows:

\section{$\mathrm{RET}=\mathrm{X}+\mathrm{X} 1 \mathrm{AT}+\mathrm{X} 2$ Turnover $+\mathrm{X} 3 \mathrm{~PB}$}

\section{Empirical analysis}

Through multiple linear regression analysis, the data are as follows: 
Table 2 results of analysis of data

\begin{tabular}{|c|c|c|c|c|c|}
\hline Stock name & $\begin{array}{l}\text { Stock } \\
\text { code }\end{array}$ & $\mathrm{R}^{2}$ & $\mathrm{~F}$ & $\mathrm{P}$ & Error \\
\hline $\begin{array}{l}\text { CITIC Securities Company } \\
\text { Limited }\end{array}$ & 600030 & 0.9981 & 262.5192 & 0.0436 & 0 \\
\hline $\begin{array}{l}\text { Sichuan Langsha Holding } \\
\text { Ltd. }\end{array}$ & 600137 & 0.9986 & 351.9756 & 0.0377 & 0 \\
\hline $\begin{array}{l}\text { Beijing Hualian Hypermarket } \\
\text { Co., Ltd. }\end{array}$ & 600361 & 0.9993 & 762.3797 & 0.0256 & 0 \\
\hline $\begin{array}{c}\text { Southwest Securities Co., } \\
\text { Ltd. }\end{array}$ & 600369 & 0.9995 & 981.2403 & 0.0226 & 0 \\
\hline $\begin{array}{l}\text { Chinese Universe Publishing } \\
\text { and Media Co., Ltd. }\end{array}$ & 600373 & 0.9977 & 215.3923 & 0.0481 & 0 \\
\hline $\begin{array}{l}\text { Beijing Bashi Media Co., } \\
\text { Ltd. }\end{array}$ & 600386 & 0.9765 & 20.8041 & 0.1532 & 0.0001 \\
\hline Heilan Home Co., Ltd. & 600398 & 0.9977 & 215.7944 & 0.0481 & 0 \\
\hline $\begin{array}{l}\text { Jiangsu Hongdou Industry } \\
\text { Co., Ltd. }\end{array}$ & 600400 & 0.9993 & 740.0733 & 0.026 & 0 \\
\hline $\begin{array}{l}\text { Xinjiang Tianrun Dairy Co., } \\
\text { Ltd. }\end{array}$ & 600419 & 0.9982 & 274.8863 & 0.0426 & 0.0001 \\
\hline $\begin{array}{l}\text { Beijing Sanyuan Foods Co., } \\
\text { Ltd. }\end{array}$ & 600429 & 0.9987 & 384.4183 & 0.036 & 0 \\
\hline Qingdao Haier Co., Ltd. & 600690 & 0.9991 & 544.8324 & 0.0303 & 0 \\
\hline $\begin{array}{l}\text { Chang Chun Eurasia Group } \\
\text { Co., Ltd. }\end{array}$ & 600697 & 0.9989 & 453.8569 & 0.0332 & 0 \\
\hline $\begin{array}{l}\text { Nanning Department Store } \\
\text { Co., Ltd. }\end{array}$ & 600712 & 0.992 & 608.2485 & 0.0287 & 0 \\
\hline $\begin{array}{l}\text { Chongqing Department Store } \\
\text { Co., Ltd. }\end{array}$ & 600729 & 0.991 & 579.0239 & 0.0294 & 0 \\
\hline $\begin{array}{l}\text { Jiangsu Chunlan } \\
\text { Refrigerating Equipment } \\
\text { Stock Co., Ltd. }\end{array}$ & 600854 & 0.9986 & 348.017 & 0.0379 & 0 \\
\hline $\begin{array}{l}\text { Meihua Holdings Group Co., } \\
\text { Ltd. }\end{array}$ & 600873 & 0.9976 & 208.6676 & 0.0489 & 0.0001 \\
\hline $\begin{array}{c}\text { Inner Mongolia Yili } \\
\text { Industrial Group Co., Ltd. }\end{array}$ & 600887 & 0.9985 & 326.8551 & 0.0391 & 0 \\
\hline China Film Co., Ltd. & 600977 & 0.9985 & 342.2096 & 0.0382 & 0 \\
\hline $\begin{array}{c}\text { Guotai Junan Securities Co., } \\
\text { Ltd. }\end{array}$ & 601211 & 0.9981 & 261.8634 & 0.0437 & 0 \\
\hline $\begin{array}{l}\text { Central China Securities Co., } \\
\text { Ltd. }\end{array}$ & 601375 & 0.9985 & 327.8897 & 0.039 & 0 \\
\hline Shanghai Film Co., Ltd. & 601595 & 0.9775 & 21.6759 & 0.1502 & 0.0005 \\
\hline Huatai Securities Co., Ltd. & 601688 & 0.9977 & 218.725 & 0.0478 & 0 \\
\hline $\begin{array}{l}\text { Jiangsu Phoenix Publishing } \\
\text { and Media Corporation } \\
\text { Limited }\end{array}$ & 601928 & 0.9975 & 200.9873 & 0.0498 & 0 \\
\hline $\begin{array}{c}\text { Yonghui Superstores Co., } \\
\text { Ltd. }\end{array}$ & 601928 & 0.9308 & 6.7208 & 0.2631 & 0.0004 \\
\hline $\begin{array}{c}\text { Zhejiang Red Dragonfly } \\
\text { Footware Co., Ltd. }\end{array}$ & 603116 & 0.9811 & 25.9451 & 0.1375 & 0 \\
\hline $\begin{array}{c}\text { Jiangsu Sunrain Solar Energy } \\
\text { Co., Ltd. }\end{array}$ & 603366 & 0.9985 & 336.2929 & 0.0385 & 0 \\
\hline Juewei Food Co., Ltd. & 603517 & 0.9258 & 6.2373 & 0.2724 & 0.0002 \\
\hline $\begin{array}{l}\text { Zhejiang Langdi Group Co., } \\
\text { Ltd. }\end{array}$ & 603726 & 0.999 & 516.64 & 0.0311 & 0 \\
\hline $\begin{array}{l}\text { Shanghai Flyco Electrical } \\
\text { Appliance Co., Ltd. }\end{array}$ & 603868 & 0.9981 & 268.9833 & 0.0431 & 0 \\
\hline $\begin{array}{l}\text { Ningbo Peacebird Fashion } \\
\text { Co., Ltd. }\end{array}$ & 603877 & 0.9988 & 426.4835 & 0.0342 & 0 \\
\hline
\end{tabular}

As can be seen from the table, only P value of 5 stocks in the 30 groups is greater than or equal to 
0.05 , does not meet the requirements, and the remaining 25 stock data meet the conditions.

\section{The main conclusions}

Through the empirical analysis of multiple linear regression, we can draw the following conclusions:

(1) the investor concern degree constructed by the WeChat index has a significant correlation with the stock returns.

(2) when the investor's attention is high in the current week, the stock returns will have an impact on the next week, and there is a positive correlation between the two.

\section{References}

[1] Deng Rui. Study on the relationship between investor's priority concern and stock returns in China's securities market -- An Empirical Study Based on Baidu index [D]. 2016 of Southwestern University of Finance and Economics

[2] Ying Qianwei, Luo Dangwei, Kong Dongmin. Investor attention, institutional ownership and stock returns -- new evidence based on the Baidu index, [J] financial quarterly, 2014, 8 (2): 74-94

[3] Zhu Yuan. The impact of investor attention on stock returns -- a study based on Baidu index [J]. Hainan finance, 2014, (11): 14-18

[4] Wang Zhen, Hao gang. The impact of investor attention on stock returns [J]. Xinjiang finance and economics, 2013, (5): 14-21

[5] Yu Qingjin, Zhang Bing. Investors limited attention and stock returns -- An Empirical Study takes the Baidu index as the degree of concern [J]. financial research, 2012, (8): 152-165

[6] Zhang Jide, Liao Wei, Zhang Rongwu. Ordinary investors pay attention to the volume and price research of stock market trading, based on the empirical study of Baidu index, $[\mathrm{J}]$. accounting research, 2014, (8): 52-60

[7] $\mathrm{Hu}$ Changsheng,Xia Fanjie. Investor attention, the cold door stock effect and stock returns[J]. Research in financial economics, 2016,(6):13-27

[8] Rao Yulei,Peng Diefeng,Cheng Dachao. Will media attention lead to abnormal returns for stocks? -- empirical evidence from China's stock market[J]. System engineering theory and practice,2010,30(2):287-29R7

[9] Lin Peng and Wei Xiong. Investor Attention, Overconfidence and Category Learning[J]. Journal of Financial Econom—ics, 2006, 80: 565 602.

[10]Barber,Br8d M. and Terrance Odean. All That Glitters; The Effect of Attention and News on the Buying BehaVior of Individual and Institutional Investors[J]. Review of Financial Studies, 2008, 21(2): 785818 .

[11]Yu Yuan. Attention and Trading[J]. Journal of Financial Economics, 2009, 104: 401—409.

[12]Gerv8is S. , Kanie1 R. and D. H. Mingelgrin. The High-volume Return Premium[J]. The Journal of Finance, 2001, 56: 877-919. 